\title{
Immunology of progressive multifocal leukoencephalopathy
}

Jelcic, Ivan ; Jelcic, Ilijas ; Faigle, Wolfgang ; Sospedra, Mireia ; Martin, Roland

\begin{abstract}
The high prevalence of asymptomatic JC polyomavirus (JCV) infection in the general population indicates coexistence with the human host and efficient immune control in healthy individuals. For unknown reasons, kidney-resident archetypic JCV strains can turn into neurotropic JCV strains which in hereditary or acquired states of immunodeficiency cause opportunistic infection and cytolytic destruction of glial cells or granule cell neurons resulting in progressive multifocal demyelination in the central nervous system (CNS) or cerebellar atrophy, respectively. Immunomodulatory or immunosuppressive therapies with specific monoclonal antibodies including natalizumab, efalizumab, and rituximab have increased the risk of progressive multifocal leukoencephalopathy (PML) among treated patients, highlighting that symptomatic JCV infection of the CNS is associated with disturbances of adaptive immunity affecting B cells, antibodies, and CD4(+) and/or CD8(+) T cells. To date, no specific therapy to overcome PML is available and the only way to eliminate the virus from the CNS is to reconstitute global immune function. However, since the identification of JCV as the causative agent of PML 40 years ago, it is still not fully understood which components of the immune system prevent the development of PML and which immune mechanisms are involved in eliminating the virus from the CNS. This review gives an update about adaptive JCV-specific immune responses.
\end{abstract}

DOI: https://doi.org/10.1007/s13365-014-0294-y

Posted at the Zurich Open Repository and Archive, University of Zurich ZORA URL: https://doi.org/10.5167/uzh-111098

Journal Article

Accepted Version

Originally published at:

Jelcic, Ivan; Jelcic, Ilijas; Faigle, Wolfgang; Sospedra, Mireia; Martin, Roland (2015). Immunology of progressive multifocal leukoencephalopathy. Journal of Neurovirology, 21(6):614-622.

DOI: https://doi.org/10.1007/s13365-014-0294-y 


\section{Immunology of Progressive Multifocal Leukoencephalopathy}

Ivan Jelcic $^{1}$, Ilijas Jelcic ${ }^{1} *$, Wolfgang Faigle ${ }^{1}$, Mireia Sospedra ${ }^{1}$ and Roland Martin ${ }^{1} * *$

* equally contributing authors

${ }^{1}$ Neuroimmunology and Multiple Sclerosis Research Section, Department of Neurology, University Hospital Zurich, 8091 Zurich, Switzerland

** Corresponding Author:

roland.martin@usz.ch

phone: +41 - 442551125

fax: $\quad+41-442558966$ 


\begin{abstract}
The high prevalence of asymptomatic JC polyomavirus (JCV) infection in the general population indicates coexistence with the human host and efficient immune control in healthy individuals. For unknown reasons kidney-resident archetypic JCV strains can turn into neurotropic JCV strains which in hereditary or acquired states of immunodeficiency cause opportunistic infection and cytolytic destruction of glial cells or granule cell neurons resulting in progressive multifocal demyelination in the central nervous system (CNS) or cerebellar atrophy, respectively. Immunomodulatory or -suppressive therapies with specific monoclonal antibodies including natalizumab, efalizumab and rituximab have increased the risk of progressive multifocal leukoencephalopathy (PML) among treated patients, highlighting that symptomatic JCV infection of the CNS is associated with disturbances of adaptive immunity affecting B cells, antibodies, $\mathrm{CD}^{+}$and/or $\mathrm{CD}^{+} \mathrm{T}$ cells. To date, no specific therapy to overcome PML is available and the only way to eliminate the virus from the CNS is to reconstitute global immune function. However, since the identification of JCV as the causative agent of PML 40 years ago, it is still not fully understood, which components of the immune system prevent the development of PML and which immune mechanisms are involved in eliminating the virus from the CNS. This review gives an update about adaptive JCV-specific immune responses.
\end{abstract}

Keywords: JCV - CNS infection - progressive multifocal leukoencephalopathy - natalizumab - adaptive immunity antigen specificity 


\section{Introduction}

JC polyoma virus (JCV) is a particularly instructive example to learn more about the interplay between viral and host immune factors. Archetypic JCV strains infect the majority of healthy humans, primarily persist in the kidney, urinary tract, but also hematopoietic progenitor cells and niches including B cells (Egli et al, 2009; Frohman et al, 2014; Major, 2010). As long as the individual's immune function remains intact, JCV infection will not cause disease. In contrast, in situations of compromised immune control, JCV variants with altered tropism for oligodendrocytes or granule cell neurons cause severe destruction in the white or gray matter leading to progressive multifocal leukoencephalopathy (PML), JCV encephalitis or granule cell neuronopathy (GCN), respectively (Gheuens et al, 2013). Opportunistic JCV infection of the central nervous system (CNS) occurs in the context of hereditary (e.g. idiopathic CD4 lymphopenia, hyper IgE syndrome) or acquired states of immunodeficiency (symptomatic human immunodeficiency virus (HIV) infection, cancer, chemotherapy, organ transplantation), but has also been associated recently with immunomodulatory or -suppressive treatments of autoimmune diseases (e.g. natalizumab, rituximab, efalizumab) (Gillespie et al, 1991; Kleinschmidt-DeMasters and Tyler, 2005; Major, 2010; Zonios et al, 2008).

In contrast to urinary excreted archetypic JCV strains, PML-associated JCV genotypes and genotype variants present characteristic mutations of the major capsid protein VP1 and rearrangements of the non-coding control region (NCCR), which probably allow entry and propagation in the CNS as well as preferential tropism for glial cells or neurons (Dang et al, 2012; Gorelik et al, 2011; Major, 2010; Reid et al, 2011). Moreover, whereas archetype JCV is secreted in the urine of healthy donors and PML patients and most probably circulates in the general population, PML-associated JCV NCCR rearrangements and VP1 mutations are only found in blood and CSF of PML patients (Reid et al, 2011). Up to date it is not clear, whether PML-associated alterations of the JCV genome occur inside or outside of the CNS and which mechanisms contribute to their occurrence or selection (Gorelik et al, 2011; Marshall et al, 2014; Reid et al, 2011).

How JCV accesses the CNS is unclear, but probably involves a hematogenous rather than a neural route: JCV enters the body via the upper respiratory tract, infects cells in the tonsils followed by persistent infection of $\mathrm{CD}^{+} 4^{+}$progenitor cells in the bone marrow and other hematopoietic niches. Under conditions of immunocompromise or -modulation the virus mobilizes from the bone marrow to the peripheral blood via CD34 ${ }^{+}$progenitor cells, B cells and/or other peripheral blood leukocyte subsets (Brew et al, 2010; Frohman et al, 2014; Houff et al, 1988). Whether JCV is attached to peripheral blood leukocytes or whether these cells are infected and active viral replication or transcription occurs remains to be elucidated. Either the migration of JCV-carrying peripheral blood leukocytes through the blood-brainbarrier or crossing the barrier by infecting endothelial cells and reaching the brain as free virions may lead to viral entry to CNS tissue (Chapagain and Nerurkar, 2010). 
To date, there is no treatment to prevent symptomatic JCV infection of the CNS. Currently, the only strategy to overcome PML is to restore general immune competence and immune surveillance of the CNS (Du Pasquier and Koralnik, 2003; Major, 2010). This in turn can lead to an immune reconstitution inflammatory syndrome (IRIS), which is usually induced after washout of natalizumab by plasmapheresis in multiple sclerosis (MS) patients or initiation of highly active antiretroviral therapy (HAART) in AIDS (Cinque et al, 2003; Tan et al, 2011; Tan et al, 2009). PML-IRIS is characterized by massive immune cell infiltration and prominent inflammation of the JCV-infected CNS tissue usually leading to acute neurological deterioration, but also effective elimination of JCV by killing infected cells (Aly et al, 2011; Gheuens et al, 2011; Tan et al, 2011). The occurrence of IRIS in the CNS can be dangerous since it may cause additional damage in the brain and even lead to death of the patient by tissue swelling if not at least temporarily attenuated by immunosuppression (Tan et al, 2009). However, a substantial proportion (20-47\%) of natalizumabassociated PML patients do not clear JCV DNA from cerebrospinal fluid (CSF) despite IRIS (Dahlhaus et al, 2013; Ryschkewitsch et al, 2010). The significance of JCV persistence in the CSF despite clinically stably disease course after IRIS is unclear. In the following sections we will summarize the current facts and concepts concerning immunology of PML and at the end we will provide the reader with important open questions in this field.

\section{Humoral immune responses during JCV infection}

Despite identification of JCV as the causative agent of PML in 1971 (Padgett et al, 1971), it is until now not fully understood, which component/s of the immune system prevent the occurrence of PML in the vast majority of JCVinfected individuals. The immunocompromised conditions promoting PML are characterized by loss of immune cells and/or perturbed function of adaptive immunity at several levels usually affecting B cells/antibodies, $\mathrm{CD}^{+}$and $\mathrm{CD} 8^{+} \mathrm{T}$ cells (Beltrami and Gordon, 2014; Du Pasquier et al, 2004; Gillespie et al, 1991; Major, 2010; Stuve, 2008).

Seropositivity for JCV VP1-specific antibodies is currently most widely used to diagnose JCV infection and utilized for risk stratification in the context of natalizumab treatment for MS patients. 54\% of MS patients are JCV-seropositive, tested in a 2-step assay (Gorelik et al, 2010). However, JCV viremia was observed in patients that were seronegative for anti-JCV VP1 antibodies, indicating that testing JCV-specific antibodies might not be sufficient to stratify the risk for some natalizumab-treated MS patients (Major et al, 2013). Interestingly, serum JCV VP1-specific antibody levels are increased in patients at onset of natalizumab-associated PML compared to natalizumab-treated MS patients (Trampe et al, 2012; Warnke et al, 2013; Warnke et al, 2014). PML survivors in the context of AIDS show significant increases in JCV-specific T cells and IgG responses in the peripheral blood, which are positively correlated with peripheral CD4 ${ }^{+} \mathrm{T}$ cell counts (Khanna et al, 2009). PML patients show generally JCV-specific oligoclonal IgG bands in the CSF and elevated intrathecal JCV VP1-specific antibodies with further increase at onset of IRIS (Aly et al, 2011; Sindic et al, 1997; Warnke et al, 2014; Weber et al, 1997). This goes in line with the observation that plasma cells are prominent 
among the brain immune infiltrates in PML-IRIS (Aly et al, 2011; Metz et al, 2012). The occurrence of PML during immunomodulatory treatments which affect B cells indicates the importance of B cell functions for controlling JCV. Rituximab depletes $\mathrm{CD} 20^{+} \mathrm{B}$ cells and thus leads to profound perturbation of the B cell homeostasis (Carson et al, 2009; Major, 2010). It is currently unknown, if the depletion of B cells by rituximab results in PML because of reduced antibody responses against JCV, due to inefficient clearance of latently JCV-infected B cell subsets or perturbation of other functions of B cells such as antigen presentation to T cells (Cooper and Arnold, 2010). Natalizumab reduces not only the migration of $\mathrm{CD} 19^{+} \mathrm{B}$ cells and $\mathrm{CD} 138^{+}$plasma cells through the blood-brain-barrier (Stuve et al, 2006b), but also perturbs B cell homing by increasing the number of memory- and marginal zone-like B cells in the peripheral blood (Planas et al, 2012). The latter conditions and the fact that natalizumab induces the migration of CD34 progenitor cells to the peripheral blood may influence the shaping and reactivation of neurotropic JCV variants (Frohman et al, 2014; Marshall et al, 2014).

Antibodies are likely involved in neutralizing free JCV virions, preventing spread of free virus, but their role for immune control during persistent JCV infection and PML is still unknown. Interestingly, a recent proof-of-concept study demonstrated that $29 \%$ of sera from MS patients lack anti-JCV neutralizing activity despite the presence of antiJCV VP1 antibodies (Diotti et al, 2014). The fact that PML patients often show strong antibody responses within the serum and the CNS compartment at onset of PML and during the course of PML (Warnke et al, 2014; Weber et al, 1997) questions the role of JCV-specific antibodies in the prevention of PML development and clearance of symptomatic JCV infection from brain. Interestingly, JCV variants with mutations in VP1 are often found in addition to prototype Mad-1 sequences in the CNS of PML patients (Gorelik et al, 2011; Reid et al, 2011). However, it is not known until now, whether mutations found in the VP1 capsid protein are driven by immune escape in order to avoid recognition by $\mathrm{JCV}$-specific antibodies or whether $\mathrm{JCV}$-specific antibodies are less effective because of intracellular persistence of JCV without proper exposition of JCV-encoded proteins at the cell membrane for direct antibody recognition. Further investigations are needed to address the role of JCV-specific antibodies with respect to recognition and neutralization capacity.

\section{Cellular immune responses during JCV infection}

\section{Role of $\mathrm{CD8}^{+} \mathrm{T}$ cells in PML}

Diseases that are associated with risk for PML development and PML progression are often characterized by an attenuated $\mathrm{T}$ cell immune surveillance with loss of JCV-specific T cells (Koralnik et al, 2001). MS patients under natalizumab show in contrast to immunodeficiency disorders overall normal peripheral JCV-specific T cell responses, but natalizumab-associated inhibition of $\mathrm{T}$ cell entry into the brain, and hence compromise of immunosurveillance of the CNS is considered a pivotal factor for PML (Chalkias et al, 2014; Jilek et al, 2010). Numerous studies have 
evaluated JCV-specific T cell responses with respect to antigen specificity, effector function and T cell subpopulations. Initial analysis of peripheral and CSF immune responses in PML survivors pointed to the importance of JCV VP1specific $\mathrm{CD}^{+} \mathrm{T}$ cells for better prognosis of PML (Du Pasquier et al, 2005; Du Pasquier et al, 2004; Gheuens et al, 2011). JCV-specific CD8 ${ }^{+} \mathrm{T}$ cells appear ideally suited for elimination of JCV in PML, since their "recognition structures", i.e. HLA-class I molecules are expressed on neurons, oligodendrocytes and astrocytes. Characterization of brain samples from PML patients demonstrated brain infiltrates particularly consistent of $\mathrm{CD}^{+} \mathrm{T}$ cells (Wuthrich et al, 2006). The proximity of $\mathrm{CD}^{+} \mathrm{T}$ cell infiltrates to JCV-infected glial cells indicated the recognition of the infected target cells. Another cross-sectional study of brain samples from HIV-patients who developed PML-IRIS proved the enrichment of cytotoxic $\mathrm{CD}^{+} \mathrm{T}$ cell infiltrates in the brain and their co-localization with JCV-infected oligodendrocytes in the context of IRIS (Martin-Blondel et al, 2013). Both studies included either HIV ${ }^{+}$donors and/or donors with lymphopenic and immunosuppressed conditions having as hallmark a global reduced number of CD4 ${ }^{+} \mathrm{T}$ cells. In addition, a recent survey of five brain biopsies from natalizumab-associated PML-IRIS patients revealed in four out of five cases brain infiltrates dominated by $\mathrm{CD}^{+} \mathrm{T}$ cells which appeared to be present in adjacent white and gray matter (Metz et al, 2012). In fact this might vary between patients or over time, since an in depth analysis of a brain biopsy from a PML-IRIS patient revealed abundant infiltration of JCV VP1-specific $\mathrm{CD}^{+} \mathrm{T}$ cells besides brain-infiltrating JCV VP1-specific CD8 ${ }^{+}$T cells (Aly et al, 2011; Yousef et al, 2012).

In the case of JCV GCN, which is characterized by productive infection of cerebellar granule cell neurons, one would expect a crucial role of $\mathrm{CD}^{+} \mathrm{T}$ cells in clearing JCV-infected neurons since these cells lack HLA class II expression (Dang and Koralnik, 2013). Indeed, a first case of natalizumab-associated JCV GCN with IRIS demonstrated abundant infiltration of $\mathrm{CD}^{+} \mathrm{T}$ cells (Schippling et al, 2013). At the current stage, existing data indicate that CD8 ${ }^{+} \mathrm{JCV}^{-\mathrm{specific}}$ $\mathrm{T}$ cells are required as effector cells to eliminate JCV from the brain.

\section{Role of $\mathrm{CD4}^{+} \mathrm{T}$ cells in PML}

There is increasing evidence that $\mathrm{CD}^{+} \mathrm{T}$ cell immunity is also pivotal for controlling JCV infection. This is supported by the frequent occurrence of PML in the context of compromised $\mathrm{CD} 4^{+} \mathrm{T}$ cell immune surveillance, most notably AIDS, but also malignancies, transplant therapy and idiopathic CD4 ${ }^{+}$lymphopenia (Gillespie et al, 1991; Zonios et al, 2008). Recovery of $\mathrm{CD}^{+} \mathrm{T}$ cell responses leads to elimination of JCV from the CNS of AIDS patients (Gasnault et al, 2003). Generally, AIDS-associated PML-survivors reveal significant increases in JCV-specific CD $4^{+} \mathrm{T}_{\text {cells }}$ as well as IgG responses (Khanna et al, 2009). Reduced $\mathrm{CSF} \mathrm{CD} 4^{+} / \mathrm{CD}^{+} \mathrm{T}$ cell ratio during natalizumab treatment indicates that entry of $\mathrm{CD}^{+} \mathrm{T}$ cells to the CNS is blocked much more efficiently than that of $\mathrm{CD}^{+} \mathrm{T}$ cells (Planas et al, 2012; Stuve et al, 2006a). Albeit often at lower numbers than $\mathrm{CD}^{+} \mathrm{T}$ cells, $\mathrm{CD} 4^{+} \mathrm{T}$ cells are also present or even found at higher numbers in CNS infiltrates during natalizumab-associated PML-IRIS (Aly et al, 2011). Moreover, widespread 
expression of HLA class II was observed in JCV-infected brain tissue during natalizumab-associated PML-IRIS, supporting the notion that brain-infiltrating CD4 ${ }^{+} \mathrm{T}$ cells are essential in clearing JCV (Aly et al, 2011).

Recent studies demonstrated strong associations of certain HLA class II alleles with JCV-specific immune responses. Thereby, heterozygotic HLA-DRB $1 * 04: 01^{+}$donors revealed very low or even absent peripheral $\mathrm{T}$ cell responses to $\mathrm{JCV}$, but potent JCV-specific antibody responses, proving a dominant-negative effect of this allele on JCV-specific T cell responses (Jelcic et al, 2013). Alleles within the HLA-DR1*15 haplotype are associated negatively, whereas the HLA-DQB1*06:03 haplotype is associated positively with JCV sero-status, evaluated by JCV-specific antibody response (Sundqvist et al, 2014). These data may indicate either a protective effect of HLA-DR1*15 haplotype on JCV infection or an effective immune control of JCV by CD4 $4^{+} \mathrm{T}$ cells in HLA-DR $1 * 15$-positive donors which does not require production of $\mathrm{JCV}$-specific antibodies. A less effective $\mathrm{JCV}$-specific $\mathrm{CD}^{+} \mathrm{T}$ cell control with higher viral turnover may result in a chronically higher stimulation of the JCV-specific B cells and increased production of JCVspecific antibodies.

The in depth analysis of brain infiltrates from a natalizumab-associated PML-IRIS patient revealed abundant and clonally expanded $\mathrm{CD}^{+} \mathrm{T}$ cells specific for JCV VP1 epitopes and HLA class II molecules of the HLA-DR1*15 haplotype (Aly et al, 2011; Yousef et al, 2012). Further characterization of these brain-infiltrating VP1-specific T cell clones (TCC) demonstrated recognition of individual JCV VP1 peptides in the context of multiple HLA-DR and -DQ molecules, a phenomenon termed HLA cross-restriction (Figure 1) (Yousef et al, 2012). This ability to use multiple restriction elements to recognize the same and/or different peptides could ensure a more efficient activation since it enhances binding avidity and allows still activation in the case of limited expression of one restriction element (specific HLA molecule) in the tissue. An additional strategy of brain-infiltrating $\mathrm{CD}^{+} \mathrm{T}$ cells included a TCR bias for the immunodominant $\mathrm{VP} 1_{34-48}$ peptide of five different TCCs with almost identical TCR $\alpha$ - and $\beta$-chains but different sequences in the CDR3 regions and associated J-chains (Figure 1) (Yousef et al, 2012). The described TCR bias in brain-infiltrating JCV-specific $\mathrm{CD} 4^{+} \mathrm{T}$ cells explains the ability of different $\mathrm{CD} 4^{+} \mathrm{T}$ cell clonotypes to recognize the same viral epitope on a specific HLA molecule. This can be the result of continued antigenic stimulation, which leads to the selection of distinct T cell clonotypes with optimal TCR binding to an immunodominant viral epitope. TCR bias is a phenomenon which is also seen in the case of other persistent viral infections (Turner et al, 2006). Moreover, we observed brain-infiltrating CD4 ${ }^{+}$TCC with an unusual Th1-2 phenotype, secreting both interferon- $\gamma$ (IFN- $\gamma$ ) and interleukin-4 (IL-4) as well as expressing both lineage transcription factors GATA-3 and T-bet. The secretion of IFN- $\gamma$ induces the expression of HLA class I and II in the tissue, thereby enhancing antigen presentation of viral peptides whereas IL-4 is essential for promoting proliferation and differentiation of activated B cells, which explains the increasing intrathecal anti-JCV antibody production (Figure 1) (Aly et al, 2011; Yousef et al, 2012). Hence, the 
simultaneous release of both cytokines allows a more effective support of both arms of the adaptive immune system, the T cell and antibody mediated responses. Altogether, the various strategies used by brain-infiltrating JCV-specific CD4 ${ }^{+}$ T cells support their importance in mounting an efficient JCV-specific immune response (Yousef et al, 2012). Longterm resolution of PML is therefore probably not possible unless there is an efficient JCV-specific CD4 ${ }^{+} \mathrm{T}$ cell response.

Interestingly, several studies associated the risk of PML with reduced T cell responses not only with respect to certain HLA alleles but also to loss of effector function. Reduced expression of CD62L on CD4 ${ }^{+} \mathrm{T}$ cells in HIV- and natalizumab-associated PML might not only provide a novel biomarker for PML but points to an altered activation status of peripheral T cells before onset of PML (Schneider-Hohendorf et al, 2014; Schwab et al, 2013). Another study reported either no detectable JCV-specific T cell response or an aberrant JCV-specific T cell response dominated by production of anti-inflammatory IL-10, as well as higher levels of IL-10 in the CSF in MS patients with natalizumabassociated PML as opposed to MS patients without PML (Perkins et al, 2012). In HIV-associated PML patients, a higher frequency of PD-1-expressing JCV-specific $\mathrm{CD}^{+} \mathrm{T}$ cells was observed, indicating an increased exhaustion and subsequent loss of JCV-specific immune responses, which might lead to PML (Tan et al, 2012). However, these studies focused mainly on peripheral $\mathrm{T}$ cell responses, which probably differ from the functional phenotype and antigen specificity of JCV-specific T cells at the site of infection in the CNS.

\section{Antigen specificity}

JCV VP1 derived from the prototypical JC viral strain Mad-1 is currently used most commonly to asses JCV-specific antibody reactivity in serum and CSF in healthy donors, MS patients and PML patients (Gorelik et al, 2010; Sundqvist et al, 2014; Trampe et al, 2012; Warnke et al, 2013; Warnke et al, 2014). Since VP1 is the major capsid protein, it is considered the main target of antibody responses. Whether minor fractions of the general anti-JCV antibody response target other JC viral proteins, e.g. VP2 and/or VP3, remains to be determined. Furthermore, the distribution of immunodominant epitopes among VP1 and the importance of VP1 mutations found in PML-associated JCV strains (Gorelik et al, 2011) with respect to immune evasion of the antibody response remain to be determined.

First attempts to characterize immunodominant $\mathrm{CD}^{+} \mathrm{T}$ cell epitopes were undertaken by in silico prediction of the best binders of 9-mer peptides to the most common HLA class I allele HLA-A*02:01 and subsequent in vitro verification using ${ }^{51} \mathrm{Cr}$-release assays and HLA-A*02:01/JCV peptide tetramer technology (Koralnik et al, 2002). Thereby, $71 \%$ of HLA-A*02:01 ${ }^{+}$PML survivors were shown to elicit JCV-VP1 $1_{100-108}$-specific cytotoxic CD8 ${ }^{+} \mathrm{T}$ cell response, in contrast to none of PML progressors (Koralnik et al, 2002). Another immunodominant $\mathrm{CD}^{+} \mathrm{T}$ cell epitope in the context of HLA-A*02:01, JCV-VP1 ${ }_{36-44}$, was identified by epitope mapping using overlapping 18 - to 20 -mer peptides spanning the JCV VP1 sequence and functional $\mathrm{CD}^{+} \mathrm{T}$ cell lysis experiments (Du Pasquier et al, 2003). HLA class I tetramer 
staining showed, that $91 \%$ of HLA-A*02:01 ${ }^{+}$PML survivors elicit JCV-VP1 $1_{36-44}$-specific CD8 ${ }^{+} \mathrm{T}$ cells, and only $9 \%$ of PML progressors (Du Pasquier et al, 2003). We used overlapping 13- to 16-mer peptides spanning all JCV-encoded open reading frames, i.e. agnoprotein, VP1, VP2, VP3, large T antigen, small t antigen and T' antigens T'135, T'136, and T'165, and thymidine incorporation to assess T cell proliferation and to identify immunodominant epitopes within the complete JCV proteome in a cohort of 49 healthy donors (Jelcic et al, 2013). In our study, the VP1 $1_{100-109}$ peptide was represented by peptides VP1 $1_{91-105}$ and $\mathrm{VP} 1_{101-115}$ in peptide pool 6 , and the VP1 $36-44$ peptide was covered by peptide $\mathrm{VP} 1_{34-48}$ in pool 4 , with each pool containin immunodominant peptide pools. Furthermore, HLA-A*02:01-restricted JCV VP1 $100-108^{-}$and VP1 $1_{36-44^{-S p e c i f i c ~} \text { CD8 }}{ }^{+} \mathrm{T}$ cells were also detected in a brain infiltrate of a patient during PML-IRIS patient by tetramer technology (Aly et al, 2011). Interestingly, $\mathrm{CD} 4^{+} \mathrm{T}$ cells from the same brain infiltrate specimen recognized preferentially $\mathrm{VP} 1_{34-48}$ in the context of HLA-DQw6 among seven other immunodominant JCV epitopes, showing that $\mathrm{CD}^{+} \mathrm{T}$ cells and $\mathrm{CD} 4^{+} \mathrm{T}$ cells recognize related epitopes, and underscoring the relevance of JCV VP1 $1_{34-48}$ epitope (Aly et al, 2011; Yousef et al, 2012). Broad reactivity of $\mathrm{CD} 4^{+}$and $\mathrm{CD} 8^{+} \mathrm{T}$ cells against each of the $\mathrm{JCV}$ proteins was recognized in MS patients and healthy donors by using intracellular cytokine staining and flow cytometry after stimulation with 5 peptide pools, which contained overlapping 15-mer peptides with each peptide pool covering one of the viral proteins, i.e. agnoprotein, VP1, VP2, large $\mathrm{T}$ antigen and small $\mathrm{t}$ antigen (Perkins et al, 2012). In this study, different viral proteins were immunodominant in different donors and most donors showed reactivity of both $\mathrm{CD} 4^{+}$and $\mathrm{CD} 8^{+} \mathrm{T}$ cells. However, systematic mapping data for single epitopes other than HLA-A*02:01-restricted JCV VP1 $1_{100-108}$ and VP1 $1_{36-44}$ is still pending.

By using thymidine incorporation assay in our epitope mapping study, proliferation and activation of CD4 ${ }^{+} \mathrm{T}$ cells was favoured over $\mathrm{CD}^{+} \mathrm{T}$ cells as shown by carboxyfluorescein succinimidyl ester (CFSE) dilution assay. With this approach multiple immunodominant epitopes in JCV VP1 and large T antigen have been mapped in the context of multiple HLA-class II alleles (Jelcic et al, 2013). Interestingly, JCV-specific T cell responses may be directed not only against JCV VP1 and large T antigen but also against all other JCV-encoded proteins. This epitope mapping study indicates a high intra- and interindividual variability in epitope specificity and immunodominant $\mathrm{JCV} \mathrm{CD}^{+} \mathrm{T}$ cell epitopes. The analysis of brain-infiltrating $\mathrm{T}$ cells in a patient with PML-IRIS revealed not only that $\mathrm{CD}^{+} \mathrm{T}$ cells dominated over $\mathrm{CD}^{+} \mathrm{T}$ cells, and that $\mathrm{CD}^{+} \mathrm{T}$ cells recognized predominantly VP1 epitopes and to a lesser extent large $\mathrm{T}$ antigen epitopes, but also that JCV VP1-specific reactivity in the brain infiltrate specimen was considerably higher than in the CSF or peripheral blood (Aly et al, 2011). This indicates that analysis of JCV-specific immunity in the peripheral blood or CSF may not be representative for the immunological reaction at the site of CNS infection. Detailed studies of intracerebral immune responses in the context of JCV-infected neurons have not been conducted yet. 


\section{Lessons from immunological studies in PML}

PML is a serious adverse event that often leaves permanent neurological deficits and threatens the use of several highly efficient monoclonal antibodies such as natalizumab for MS treatment. In natalizumab-treated patients, risk stratification according to JCV-seropositivity, duration of treatment and prior long-term immunosuppressive therapies help to identify patients at higher risk for PML development in order to terminate treatment (Gorelik et al, 2010). Yet, we currently do not have a similarly efficacious and well-tolerated drug available for the treatment of MS patients with active disease after suspension of natalizumab treatment. Therefore, it would be highly desirable to establish prophylactic and/or therapeutic vaccination regimens.

Currently, there are no specific treatments for PML except of reconstituting immunocompentence in the brain. Until now it is not fully understood, which components of the immune system are involved in prevention or resolution of JCV infection in the brain. Open questions concerning PML immunology and JCV-specific immunity are summarized in Table 1.

Several studies have highlighted the importance of $\mathrm{CD} 4^{+}$and $\mathrm{CD} 8^{+} \mathrm{T}$ cells and B cells in JCV-specific immunity. TCR bias, avidity-enhancing HLA-cross-restriction and flexibility in T helper cell phenotype of brain-infiltrating cells as well as the large intra- and interindividual variability in epitope specificity and epitope immunodominance of peripheral JCV-specific T cells indicate that a variety of mechanisms is involved in keeping latent/persistent JCV infection in check. While it is not possible to tell at present, which cell population is most relevant, CD4 ${ }^{+} \mathrm{JCV}$-specific $\mathrm{T}$ cells probably play a major role, but the other arms of adaptive immunity are also involved. JCV VP1 may represent the best candidate for stimulating JCV-specific $\mathrm{CD}^{+} \mathrm{T}$ cell responses, and the addition of an adjuvant would additionally boost the response. However, these conclusions are based on few studies with a limited number of cases. Most of the studies with higher case numbers investigated JCV-specific immunity in the peripheral blood, and not in the CSF or brain tissue. Big caveats are immune-escaping mechanisms of JCV and counter-mechanisms of JCV-specific immunity, as well as the role of genetic factors predisposing for PML and the interplay of $\mathrm{CD} 4^{+} \mathrm{T}$ cells, $\mathrm{CD} 8^{+} \mathrm{T}$ cells and $\mathrm{B}$ cells to control latent and symptomatic JCV infection. Before vaccination of generally immunocompromised-/deficient patients some degree of immunocompetence would have to be restored. Strategies to achieve prophylactic and/or therapeutic vaccination should actively be explored, since treatments for PML are urgently needed and boosting natural immunity against JCV appears the most promising approach in this direction. We expect further studies on JCV-specific immunity to explore biomarkers of PML risk, for prognostic estimates and particularly with respect to developing vaccination approaches to prevent or treat PML. 


\section{Figure legends}

Figure 1. Mechanisms used by brain-infiltrating VP1-specific $\mathrm{CD}^{+} \mathrm{T}$ cells to mount efficient immune responses against neurotropic JC virus. These strategies include: HLA-cross-restriction, an ability of a T cell clone (TCC) to recognize the same JC viral epitope (yellow circle) on different HLA molecules presented by antigen-presenting cells (APC) and thereby enhancing avidity as well as ensuring recognition even in the case of limited expression of one of the HLA molecules; T cell receptor (TCR) bias, a phenomenon that explains the recognition of the same JC viral epitope (e.g. the immunodominant JCV peptide $\mathrm{VP}_{34-48}$ ) on a specific HLA molecule by different $\mathrm{CD} 4^{+} \mathrm{T}$ cell clonotypes; functional Th1-2 phenotype that is characterized by simultaneous secretion of IFN- $\gamma$ and IL-4, which lead to strong expression of HLA class II in the tissue and intrathecal anti-JCV antibody production. 


\section{Conflict of Interest}

The authors declare that they have no conflict of interest. 


\section{References}

Aly L, Yousef S, Schippling S, Jelcic I, Breiden P, Matschke J, Schulz R, Bofill-Mas S, Jones L, Demina V, Linnebank M, Ogg G, Girones R, Weber T, Sospedra M, Martin R (2011). Central role of JC virus-specific CD4+ lymphocytes in progressive multi-focal leucoencephalopathy-immune reconstitution inflammatory syndrome. Brain 134: $2687-702$.

Beltrami S, Gordon J (2014). Immune surveillance and response to JC virus infection and PML. J Neurovirol 20: 13749.

Brew BJ, Davies NW, Cinque P, Clifford DB, Nath A (2010). Progressive multifocal leukoencephalopathy and other forms of JC virus disease. Nat Rev Neurol 6: 667-79.

Carson KR, Evens AM, Richey EA, Habermann TM, Focosi D, Seymour JF, Laubach J, Bawn SD, Gordon LI, Winter JN, Furman RR, Vose JM, Zelenetz AD, Mamtani R, Raisch DW, Dorshimer GW, Rosen ST, Muro K, Gottardi-Littell NR, Talley RL, Sartor O, Green D, Major EO, Bennett CL (2009). Progressive multifocal leukoencephalopathy after rituximab therapy in HIV-negative patients: a report of 57 cases from the Research on Adverse Drug Events and Reports project. Blood 113: 4834-40.

Chalkias S, Dang X, Bord E, Stein MC, Kinkel RP, Sloane JA, Donnelly M, Ionete C, Houtchens MK, Buckle GJ, Batson S, Koralnik IJ (2014). JC virus Reactivation During Prolonged Natalizumab Monotherapy for Multiple Sclerosis. Ann Neurol. 75: 925-34

Chapagain ML, Nerurkar VR (2010). Human polyomavirus JC (JCV) infection of human B lymphocytes: a possible mechanism for JCV transmigration across the blood-brain barrier. J Infect Dis 202: 184-91.

Cinque P, Bossolasco S, Brambilla AM, Boschini A, Mussini C, Pierotti C, Campi A, Casari S, Bertelli D, Mena M, Lazzarin A (2003). The effect of highly active antiretroviral therapy-induced immune reconstitution on development and outcome of progressive multifocal leukoencephalopathy: study of 43 cases with review of the literature. J Neurovirol 9 Suppl 1: 73-80.

Cooper N, Arnold DM (2010). The effect of rituximab on humoral and cell mediated immunity and infection in the treatment of autoimmune diseases. Br J Haematol 149: 3-13. 
Dahlhaus S, Hoepner R, Chan A, Kleiter I, Adams O, Lukas C, Hellwig K, Gold R (2013). Disease course and outcome of 15 monocentrically treated natalizumab-associated progressive multifocal leukoencephalopathy patients. J Neurol Neurosurg Psychiatry 84: 1068-74.

Dang X, Koralnik IJ (2013). Gone over to the dark side: Natalizumab-associated JC virus infection of neurons in cerebellar gray matter. Ann Neurol. 74: 503-5

Dang X, Vidal JE, Oliveira AC, Simpson DM, Morgello S, Hecht JH, Ngo LH, Koralnik IJ (2012). JC virus granule cell neuronopathy is associated with VP1 C terminus mutants. J Gen Virol 93: 175-83.

Diotti RA, Mancini N, Clementi N, Sautto G, Moreno GJ, Criscuolo E, Cappelletti F, Man P, Forest E, Remy L, Giannecchini S, Clementi M, Burioni R (2014). Cloning of the first human anti-JCPyV/VP1 neutralizing monoclonal antibody: Epitope definition and implications in risk stratification of patients under natalizumab therapy. Antiviral Res 108: $94-103$.

Du Pasquier RA, Autissier P, Zheng Y, Jean-Jacques J, Koralnik IJ (2005). Presence of JC virus-specific CTL in the cerebrospinal fluid of PML patients: rationale for immune-based therapeutic strategies. AIDS 19: 2069-76.

Du Pasquier RA, Koralnik IJ (2003). Inflammatory reaction in progressive multifocal leukoencephalopathy: harmful or beneficial? J Neurovirol 9 Suppl 1: 25-31.

Du Pasquier RA, Kuroda MJ, Schmitz JE, Zheng Y, Martin K, Peyerl FW, Lifton M, Gorgone D, Autissier P, Letvin NL, Koralnik IJ (2003). Low frequency of cytotoxic T lymphocytes against the novel HLA-A*0201-restricted JC virus epitope VP1(p36) in patients with proven or possible progressive multifocal leukoencephalopathy. J Virol 77: 1191826.

Du Pasquier RA, Kuroda MJ, Zheng Y, Jean-Jacques J, Letvin NL, Koralnik IJ (2004). A prospective study demonstrates an association between JC virus-specific cytotoxic $\mathrm{T}$ lymphocytes and the early control of progressive multifocal leukoencephalopathy. Brain 127: 1970-8.

Egli A, Infanti L, Dumoulin A, Buser A, Samaridis J, Stebler C, Gosert R, Hirsch HH (2009). Prevalence of polyomavirus BK and JC infection and replication in 400 healthy blood donors. J Infect Dis 199: 837-46.

Frohman EM, Monaco MC, Remington G, Ryschkewitsch C, Jensen PN, Johnson K, Perkins M, Liebner J, Greenberg B, Monson N, Frohman TC, Douek D, Major EO (2014). JC Virus in CD34+ and CD19+ Cells in Patients With Multiple Sclerosis Treated With Natalizumab. JAMA Neurol 71: 596-602. 
Gasnault J, Kahraman M, de Goer de Herve MG, Durali D, Delfraissy JF, Taoufik Y (2003). Critical role of JC virusspecific CD4 T-cell responses in preventing progressive multifocal leukoencephalopathy. AIDS 17: 1443-9.

Gheuens S, Bord E, Kesari S, Simpson DM, Gandhi RT, Clifford DB, Berger JR, Ngo L, Koralnik IJ (2011). Role of CD4+ and CD8+ T-cell responses against JC virus in the outcome of patients with progressive multifocal leukoencephalopathy (PML) and PML with immune reconstitution inflammatory syndrome. J Virol 85: 7256-63.

Gheuens S, Wuthrich C, Koralnik IJ (2013). Progressive multifocal leukoencephalopathy: why gray and white matter. Annu Rev Pathol 8: 189-215.

Gillespie SM, Chang Y, Lemp G, Arthur R, Buchbinder S, Steimle A, Baumgartner J, Rando T, Neal D, Rutherford G, et al. (1991). Progressive multifocal leukoencephalopathy in persons infected with human immunodeficiency virus, San Francisco, 1981-1989. Ann Neurol 30: 597-604.

Gorelik L, Lerner M, Bixler S, Crossman M, Schlain B, Simon K, Pace A, Cheung A, Chen LL, Berman M, Zein F, Wilson E, Yednock T, Sandrock A, Goelz SE, Subramanyam M (2010). Anti-JC virus antibodies: implications for PML risk stratification. Ann Neurol 68: 295-303.

Gorelik L, Reid C, Testa M, Brickelmaier M, Bossolasco S, Pazzi A, Bestetti A, Carmillo P, Wilson E, McAuliffe M, Tonkin C, Carulli JP, Lugovskoy A, Lazzarin A, Sunyaev S, Simon K, Cinque P (2011). Progressive multifocal leukoencephalopathy (PML) development is associated with mutations in JC virus capsid protein VP1 that change its receptor specificity. J Infect Dis 204: 103-14.

Houff SA, Major EO, Katz DA, Kufta CV, Sever JL, Pittaluga S, Roberts JR, Gitt J, Saini N, Lux W (1988). Involvement of JC virus-infected mononuclear cells from the bone marrow and spleen in the pathogenesis of progressive multifocal leukoencephalopathy. N Engl J Med 318: 301-5.

Jelcic I, Aly L, Binder TM, Jelcic I, Bofill-Mas S, Planas R, Demina V, Eiermann TH, Weber T, Girones R, Sospedra M, Martin R (2013). T cell epitope mapping of JC polyoma virus-encoded proteome reveals reduced T cell responses in HLA-DRB1*04:01+ donors. J Virol 87: 3393-408.

Jilek S, Jaquiery E, Hirsch HH, Lysandropoulos A, Canales M, Guignard L, Schluep M, Pantaleo G, Du Pasquier RA (2010). Immune responses to JC virus in patients with multiple sclerosis treated with natalizumab: a cross-sectional and longitudinal study. Lancet Neurol 9: 264-72. 
Khanna N, Wolbers M, Mueller NJ, Garzoni C, Du Pasquier RA, Fux CA, Vernazza P, Bernasconi E, Viscidi R, Battegay M, Hirsch HH, Swiss HIVCS (2009). JC virus-specific immune responses in human immunodeficiency virus type 1 patients with progressive multifocal leukoencephalopathy. J Virol 83: 4404-11.

Kleinschmidt-DeMasters BK, Tyler KL (2005). Progressive multifocal leukoencephalopathy complicating treatment with natalizumab and interferon beta-1a for multiple sclerosis. N Engl J Med 353: 369-74.

Koralnik IJ, Du Pasquier RA, Kuroda MJ, Schmitz JE, Dang X, Zheng Y, Lifton M, Letvin NL (2002). Association of prolonged survival in HLA-A2+ progressive multifocal leukoencephalopathy patients with a CTL response specific for a commonly recognized JC virus epitope. J Immunol 168: 499-504.

Koralnik IJ, Du Pasquier RA, Letvin NL (2001). JC virus-specific cytotoxic T lymphocytes in individuals with progressive multifocal leukoencephalopathy. J Virol 75: 3483-7.

Major EO (2010). Progressive multifocal leukoencephalopathy in patients on immunomodulatory therapies. Annu Rev Med 61: 35-47.

Major EO, Frohman E, Douek D (2013). JC viremia in natalizumab-treated patients with multiple sclerosis. N Engl J Med 368: 2240-1.

Marshall LJ, Ferenczy MW, Daley EL, Jensen PN, Ryschkewitsch CF, Major EO (2014). Lymphocyte gene expression and JC virus noncoding control region sequences are linked with the risk of progressive multifocal leukoencephalopathy. J Virol 88: 5177-83.

Martin-Blondel G, Bauer J, Cuvinciuc V, Uro-Coste E, Debard A, Massip P, Delisle MB, Lassmann H, Marchou B, Mars LT, Liblau RS (2013). In situ evidence of JC virus control by CD8+ T cells in PML-IRIS during HIV infection. Neurology 81: 964-970.

Metz I, Radue EW, Oterino A, Kumpfel T, Wiendl H, Schippling S, Kuhle J, Sahraian MA, Gray F, Jakl V, Hausler D, Bruck W (2012). Pathology of immune reconstitution inflammatory syndrome in multiple sclerosis with natalizumabassociated progressive multifocal leukoencephalopathy. Acta Neuropathol 123: 235-45.

Padgett BL, Walker DL, ZuRhein GM, Eckroade RJ, Dessel BH (1971). Cultivation of papova-like virus from human brain with progressive multifocal leucoencephalopathy. Lancet 1: 1257-60. 
Perkins MR, Ryschkewitsch C, Liebner JC, Monaco MC, Himelfarb D, Ireland S, Roque A, Edward HL, Jensen PN, Remington G, Abraham T, Abraham J, Greenberg B, Kaufman C, LaGanke C, Monson NL, Xu X, Frohman E, Major EO, Douek DC (2012). Changes in JC virus-specific T cell responses during natalizumab treatment and in natalizumabassociated progressive multifocal leukoencephalopathy. PLoS Pathog 8: e1003014.

Planas R, Jelcic I, Schippling S, Martin R, Sospedra M (2012). Natalizumab treatment perturbs memory- and marginal zone-like B-cell homing in secondary lymphoid organs in multiple sclerosis. Eur J Immunol 42: 790-8.

Reid CE, Li H, Sur G, Carmillo P, Bushnell S, Tizard R, McAuliffe M, Tonkin C, Simon K, Goelz S, Cinque P, Gorelik L, Carulli JP (2011). Sequencing and analysis of JC virus DNA from natalizumab-treated PML patients. J Infect Dis 204: $237-44$.

Ryschkewitsch CF, Jensen PN, Monaco MC, Major EO (2010). JC virus persistence following progressive multifocal leukoencephalopathy in multiple sclerosis patients treated with natalizumab. Ann Neurol 68: 384-91.

Schippling S, Kempf C, Buchele F, Jelcic I, Bozinov O, Bont A, Linnebank M, Sospedra M, Weller M, Budka H, Martin R (2013). JCV granule cell neuronopathy and GCN-IRIS under natalizumab treatment. Ann Neurol. 74: 622-6

Schneider-Hohendorf T, Philipp K, Husstedt IW, Wiendl H, Schwab N (2014). Specific loss of cellular L-selectin on CD4+ T cells is associated with PML development during HIV infection. AIDS. 28: 793-5

Schwab N, Schneider-Hohendorf T, Posevitz V, Breuer J, Gobel K, Windhagen S, Brochet B, Vermersch P, LebrunFrenay C, Posevitz-Fejfar A, Capra R, Imberti L, Straeten V, Haas J, Wildemann B, Havla J, Kumpfel T, Meinl I, Niessen K, Goelz S, Kleinschnitz C, Warnke C, Buck D, Gold R, Kieseier BC, Meuth SG, Foley J, Chan A, Brassat D, Wiendl H (2013). L-selectin is a possible biomarker for individual PML risk in natalizumab-treated MS patients. Neurology 81: 865-71.

Sindic CJ, Trebst C, Van Antwerpen MP, Frye S, Enzensberger W, Hunsmann G, Luke W, Weber T (1997). Detection of CSF-specific oligoclonal antibodies to recombinant JC virus VP1 in patients with progressive multifocal leukoencephalopathy. J Neuroimmunol 76: 100-4.

Stuve O (2008). The effects of natalizumab on the innate and adaptive immune system in the central nervous system. J Neurol Sci 274: 39-41. 
Stuve O, Marra CM, Bar-Or A, Niino M, Cravens PD, Cepok S, Frohman EM, Phillips JT, Arendt G, Jerome KR, Cook L, Grand'Maison F, Hemmer B, Monson NL, Racke MK (2006a). Altered CD4+/CD8+ T-cell ratios in cerebrospinal fluid of natalizumab-treated patients with multiple sclerosis. Arch Neurol 63: 1383-7.

Stuve O, Marra CM, Jerome KR, Cook L, Cravens PD, Cepok S, Frohman EM, Phillips JT, Arendt G, Hemmer B, Monson NL, Racke MK (2006b). Immune surveillance in multiple sclerosis patients treated with natalizumab. Ann Neurol 59: 743-7.

Sundqvist E, Buck D, Warnke C, Albrecht E, Gieger C, Khademi M, Lima Bomfim I, Fogdell-Hahn A, Link J, Alfredsson L, Sondergaard HB, Hillert J, International Multiple Sclerosis Genetics C, Oturai AB, Hemme B, Kockum I, Olsson T (2014). JC polyomavirus infection is strongly controlled by human leucocyte antigen class II variants. PLoS Pathog 10: e1004084.

Tan CS, Bord E, Broge TA, Jr., Glotzbecker B, Mills H, Gheuens S, Rosenblatt J, Avigan D, Koralnik IJ (2012). Increased program cell death-1 expression on $\mathrm{T}$ lymphocytes of patients with progressive multifocal leukoencephalopathy. J Acquir Immune Defic Syndr 60: 244-8.

Tan IL, McArthur JC, Clifford DB, Major EO, Nath A (2011). Immune reconstitution inflammatory syndrome in natalizumab-associated PML. Neurology 77: 1061-7.

Tan K, Roda R, Ostrow L, McArthur J, Nath A (2009). PML-IRIS in patients with HIV infection: clinical manifestations and treatment with steroids. Neurology 72: 1458-64.

Trampe AK, Hemmelmann C, Stroet A, Haghikia A, Hellwig K, Wiendl H, Goelz S, Ziegler A, Gold R, Chan A (2012). Anti-JC virus antibodies in a large German natalizumab-treated multiple sclerosis cohort. Neurology 78: 173642.

Turner SJ, Doherty PC, McCluskey J, Rossjohn J (2006). Structural determinants of T-cell receptor bias in immunity. Nat Rev Immunol 6: 883-94.

Warnke C, Ramanujam R, Plavina T, Bergstrom T, Goelz S, Subramanyam M, Kockum I, Rahbar A, Kieseier BC, Holmen C, Olsson T, Hillert J, Fogdell-Hahn A (2013). Changes to anti-JCV antibody levels in a Swedish national MS cohort. J Neurol Neurosurg Psychiatry 84: 1199-205.

Warnke C, von Geldern G, Markwerth P, Dehmel T, Hoepner R, Gold R, Pawlita M, Kumpfel T, Maurer M, Stangel M, Wegner F, Hohlfeld R, Straeten V, Limmroth V, Weber T, Hermsen D, Kleinschnitz C, Hartung HP, Wattjes MP, $-18-$ 
Svenningson A, Major E, Olsson T, Kieseier BC, Adams O (2014). Cerebrospinal Fluid JC Virus Antibody Index for Diagnosis of Natalizumab-Associated Progressive Multifocal Leukoencephalopathy. Ann Neurol. doi: 10.1002/ana.24153

Weber T, Trebst C, Frye S, Cinque P, Vago L, Sindic CJ, Schulz-Schaeffer WJ, Kretzschmar HA, Enzensberger W, Hunsmann G, Luke W (1997). Analysis of the systemic and intrathecal humoral immune response in progressive multifocal leukoencephalopathy. J Infect Dis 176: 250-4.

Wuthrich C, Kesari S, Kim WK, Williams K, Gelman R, Elmeric D, De Girolami U, Joseph JT, Hedley-Whyte T, Koralnik IJ (2006). Characterization of lymphocytic infiltrates in progressive multifocal leukoencephalopathy: colocalization of CD8(+) T cells with JCV-infected glial cells. J Neurovirol 12: 116-28.

Yousef S, Planas R, Chakroun K, Hoffmeister-Ullerich S, Binder TM, Eiermann TH, Martin R, Sospedra M (2012). TCR bias and HLA cross-restriction are strategies of human brain-infiltrating JC virus-specific CD4+ T cells during viral infection. J Immunol 189: 3618-30.

Zonios DI, Falloon J, Bennett JE, Shaw PA, Chaitt D, Baseler MW, Adelsberger JW, Metcalf JA, Polis MA, Kovacs SJ, Kovacs JA, Davey RT, Lane HC, Masur H, Sereti I (2008). Idiopathic CD4+ lymphocytopenia: natural history and prognostic factors. Blood 112: 287-94. 
Table 1. Unsettled questions around JCV-specific immunobiology.

\begin{tabular}{|c|c|}
\hline $\begin{array}{l}\text { Features of JCV-specific } \\
\text { immunity }\end{array}$ & $\begin{array}{l}\text { - Which antigens and epitopes of JCV are preferentially recognized by } \\
\text { antibodies and T cells in the CNS? } \\
\text { - How important are peripheral and intrathecal JCV-specific antibodies for } \\
\text { controlling JCV infection in the CNS? } \\
\text { - What is the relevance of NK cells and other arms of the innate immunity } \\
\text { in keeping JCV at bay? } \\
\text { Which immune mechanisms of T cells are used to eliminate JCV-infected } \\
\text { neurons or glial cells? }\end{array}$ \\
\hline $\begin{array}{l}\text { Impact of host immune } \\
\text { system on JCV "life } \\
\text { cycle" and tropism }\end{array}$ & $\begin{array}{l}\text { - Does the immune system force mutations of the JCV genome and changes } \\
\text { of JCV tropism to neurons or glial cells? } \\
\text { - Are immune cells involved in the process of JCV infection of CNS tissue, } \\
\text { e.g. as Trojan horse, and when does JCV infection of CNS tissue occur? } \\
\text { Does the immune response to JCV in the CNS differ in the context of } \\
\text { neuronal or glial JCV infection? }\end{array}$ \\
\hline $\begin{array}{l}\text { Influence of JCV } \\
\text { mutations on host immune } \\
\text { control }\end{array}$ & $\begin{array}{l}\text { - Do mutations in the coding region of JCV alter JCV-specific immune } \\
\text { responses? } \\
\text { - How quickly may adaptive immune responses adjust to novel mutations in } \\
\text { the coding region of JCV? } \\
\text { - Which mechanisms do JC viruses use for immune escape? }\end{array}$ \\
\hline $\begin{array}{l}\text { Influence } \\
\text { immunotherapies on } \mathrm{JCV} \\
\text { immunity }\end{array}$ & $\begin{array}{l}\text { Which arms of JCV-specific immunity are critically influenced by } \\
\text { immunomodulatory and/or immunosuppressive drugs associated with } \\
\text { increased PML risk? }\end{array}$ \\
\hline $\begin{array}{l}\text { JCV-specific vaccination } \\
\text { strategies }\end{array}$ & $\begin{array}{l}\text { Can active and/or passive JCV-specific vaccine strategies protect against } \\
\text { or clear JCV infection of CNS? }\end{array}$ \\
\hline
\end{tabular}




\section{HLA cross-restriction}

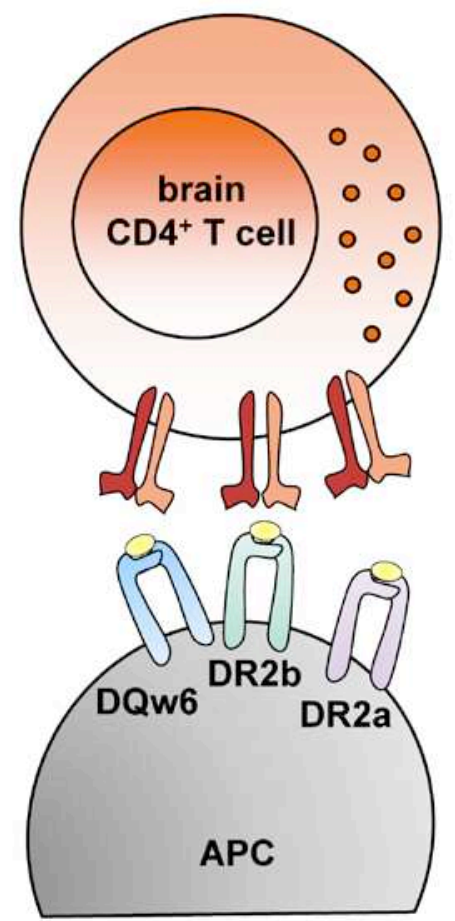

TCR bias

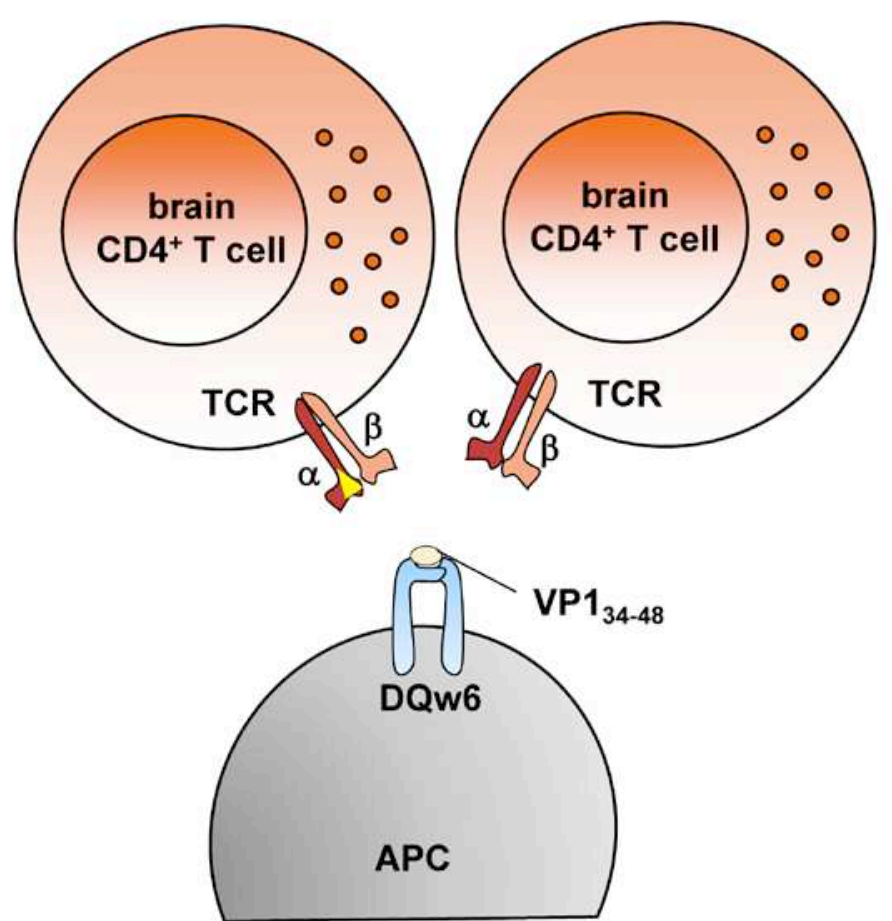

\section{Th1-2 phenotype}

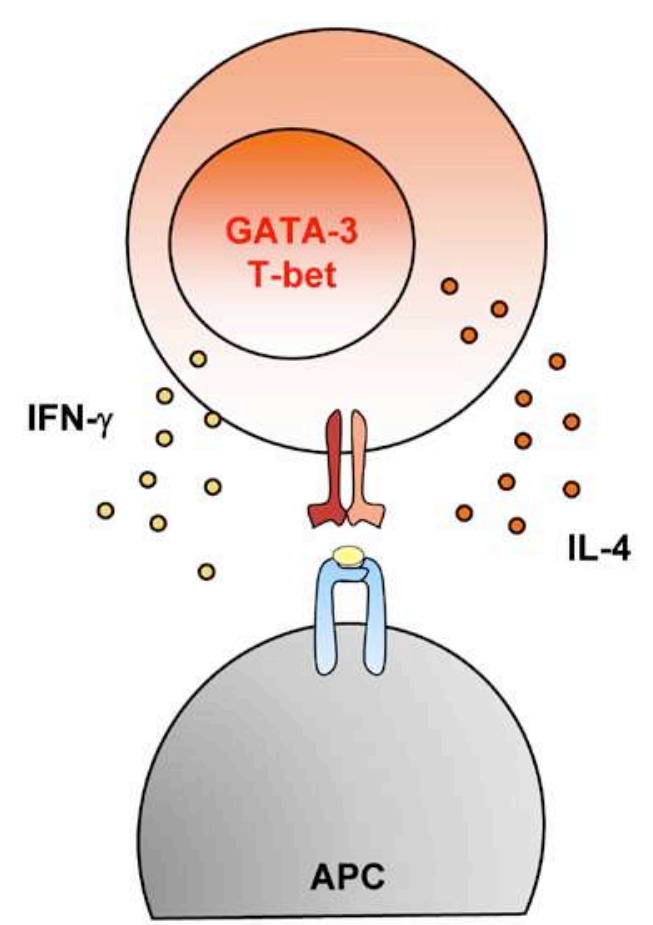

Figure 1. 